\title{
Power Generation by Harvesting Dissolved Oxygen in Water and Deoxidation Using Fuel Cells
}

\author{
Keiichi Kaneto and Sadahito Uto \\ Department of Biomedical Engineering, Osaka Institute of Technology, \\ 5-16-1 Omiya, Asahi-ku, Osaka, 535-8585, Japan \\ * Corresponding author: e-mail: keiichi.kaneto@oit.ac.jp
}

\begin{abstract}
Fuel cells harvest dissolved oxygen (DO) in water, and can be utilized by same performances to the cell in air within the rated power output. It is also found that fuel cells remove $\mathrm{O}_{2}$ from air and water in closed containers. In deoxidation, several methods, such as direct water supply, bubbling and artificial gill in DO water are studied. The ability of harvesting DO is discussed with relationships between electrical current and $\mathrm{O}_{2}$ flow rate.
\end{abstract}

Key words: biofuel cell, water, dissolved oxygen, output

\section{INTRODUCTION}

Animals are breathing air, which contains $\mathrm{O}_{2}$ by $20.9 \%$. On the other hand, fishes live in water in spite of only $8 \mathrm{ppm}$ of $\mathrm{O}_{2}$. Living creatures started from sea and produced $\mathrm{O}_{2}$ by photosynthesis from $\mathrm{CO}_{2}$ in air since thousand million years ago. We have interested in, whether fuel cell works taking dissolved oxygen (DO) in water. Few reports on this topic have been found except for microbial fuel cells $[1,2]$. Research studies on biofuel cells $[3,4]$ have been mainly devoted to improve performances of anode catalysts and ion exchange membrane from bio energy to electrical power. In this report, characteristics of biofuel cells (non-microbe) which harvest DO, are described.

It should be noted that the $\mathrm{O}_{2}$ contents are equilibrated at the interface between air and water by the ambient condition. The fact indicates that the same number of $\mathrm{O}_{2}$ molecules exchanged at the air/water interface. The difference is diffusion rates of $\mathrm{O}_{2}$ in air and water, which determines performances of fuel cells. The small content of DO in water originates from the poor solubility, indicating favorable in release of $\mathrm{O}_{2}$ in water.

Oxygen is crucial substance for all living creatures, and also cultivates putrefaction and accelerates corrosion. Removal of $\mathrm{O}_{2}$ (deoxidation) is the key issue to preserve foods and medicines for long term, in combination of wrapping them by barrier films. Possibility and ability of deoxidation of DO water by fuel cell are also described.

\section{FABRICATION OF BIOFUEL CELL}

Schematics of a system to evaluate performances of fuel cells [5-7] are shown in Fig.1. The system was composed of four parts, (a) fuel cell, (b) fuel tank, (c) external circuit to evaluate cell performance, (d) water from open container and (e) DO gas from closed container. L-ascorbic acid (0.5M AsA) was used for the fuel, which was circulated by a pump to anode with the rate of $2 \mathrm{~mL} / \mathrm{min}$. The electrical output from the fuel cell was measured by the external circuit for the cell voltage $\left(E_{\text {cell }}\right)$ and current $(i)$ by changing the load resistance $\left(R_{\mathrm{L}}\right)$.

DO was supplied to the cathode by methods of direct
DO water and gas harvesting DO by an artificial gill. Gills were fabricated by silicon tube, because it is known for the large oxygen permeability and commonly available (from AS ONE). The tube with the inner and outer diameters of $2.5 \mathrm{~mm} \times 3.5 \mathrm{~mm}$ with the lengths of 1.0 and $2.5 \mathrm{~m}$ was used. In the long tube, a steel wire with diameter of $1.6 \mathrm{~mm}$ was inserted to keep the shape in coil. The diameter of coils was $5 \mathrm{~cm}$ with lengths of 3 and $6 \mathrm{~cm}$. The gas from the gill was circulated to cathode by the rate of $100 \sim$ $150 \mathrm{~mL} / \mathrm{min}$. Flow rates of DO water were $2 \sim 5 \mathrm{~mL} / \mathrm{min}$.

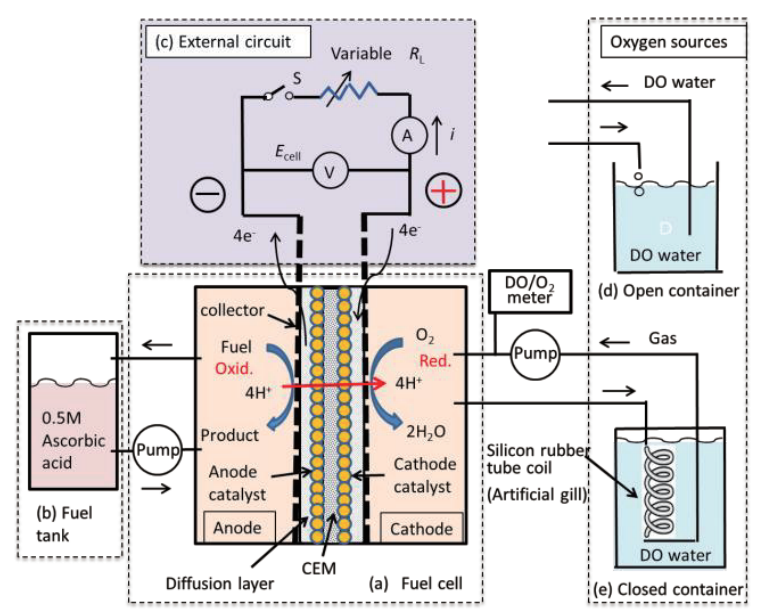

Fig.1 Schematic drawing for harvesting DO in water using fuel cell

The structure of biofuel cell is shown in Fig.2. The core laminate was composed of anode, cathode catalysts and a cation exchange membrane (CEM). A composite film of poly(3,4-ethylenedioxythiophene) polystyrene sulfonate (PEDOT*PSS) and single walled-carbon nanotube (SWCNT) was used for the anode catalyst [7]. This anode catalyst demonstrated the best performance for AsA fuel cell. Pt-black (PT-B) pasted on carbon sheet by the amount of $3 \mathrm{mgcm}^{-2}$ was employed for the cathode catalyst. Nafion (N117) was used for the CEM. The surface area 
of catalysts were $1 \times 1 \mathrm{~cm}^{2}$. The typical performance of the cells, namely, open circuit voltage $\left(E_{0}\right)$ was $0.55 \mathrm{~V}$, maximum output power $\left(P_{\max }\right)$ and maximum current $\left(I_{\max }\right)$ were $1.2 \sim 2.0 \mathrm{~mW}$ and $10 \sim 15 \mathrm{~mA}$, respectively. The experiment was carried out at air conditioned room temperature of ca. $22{ }^{\circ} \mathrm{C}$. The water temperature was assumed to be equilibrated to the room temperature. The cell performances somehow depended on assembly of the core laminates. The detail structure and materials are described in our previous papers [5-8].

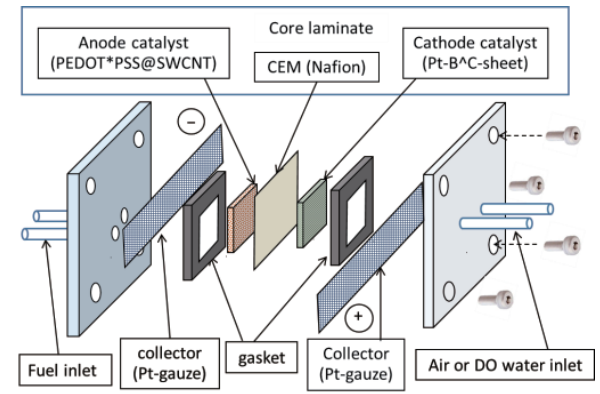

Fig.2 Structure of the biofuel cell

\section{POWER GENERATION USING DO IN WATER}

3.1 Harvesting DO directly from water

The cell performance was evaluated from polarization curves[5-8], that is, $i(\mathrm{~A})$ dependence of $E_{\text {cell }}(\mathrm{V})$ and power $P=i \times E_{\text {cell }}(\mathrm{W})$. It is noted that $i$ and $P$ were values per unit area $\left(\mathrm{cm}^{2}\right)$ in this experiment. The typical results of polarization curve are shown in Fig.3, which were obtained by the cell operated using air, DO water and DO sea water using Fig.1 (d) open container. The definition of cell parameters $E_{0}, P_{\max }, E_{\max }$ and $I_{\max }$ are also shown. $E_{0}$ was obtained at the switch $\mathrm{S}$ off in Fig.1 (c). $P_{\max }, E_{\max }$ and $I_{\max }$ are the values of $P, E_{\text {cell }}$ and $i$ obtained at the maximum $P$.

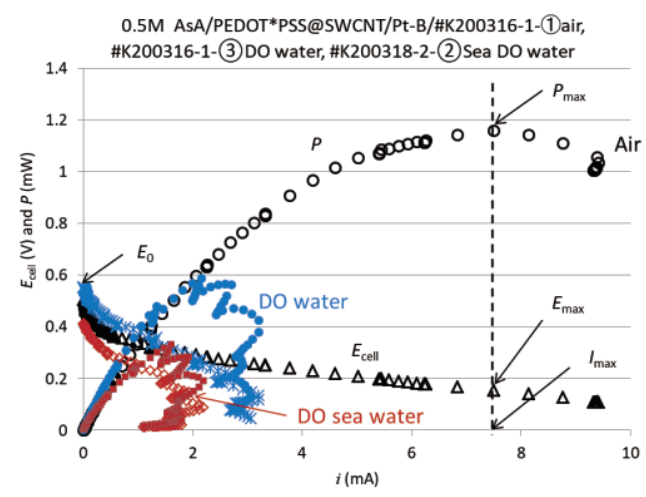

Fig.3 Typical polarization curves of the cells using air, DO water and DO sea water, and definition of cell parameters.

The $P$ obtained by feeding DO water directly showed collapsed curves at large $i$ as shown in Fig.3. This is resulted from oxygen deficiency due to small $\mathrm{O}_{2}$ diffusion in water. However, it should be noted that the fuel cell by DO water can be practically utilized within the rated power output $<2 \mathrm{~mA}$, because the drop of $E_{\text {cell }}$ were same between air and DO water. The performance of cell fed by quasi-sea water $(3.4 \% \mathrm{NaCl}$ added to $\mathrm{DO}$ water) was unfavorable to use. The decrease of $E_{0}$ is supposed to originate from polarization at the interface of catalyst. The poor performance and enhanced oxygen deficiency feature probably resulted from lower deoxidation and diffusion in salt water due to strong interaction of ions and oxygen.

\subsection{Harvesting DO using silicon coil gill}

In this experiment, silicon coil gill was placed in DO water in open container, and in air for comparison. Before measurements, inside of the gill was purged with $\mathrm{N}_{2}$ gas to remove air. Upon circulation of the inner gas and discharge cell at $R_{\mathrm{L}}=11 \Omega, \mathrm{O}_{2}$ contents in the silicon tube leveled off in a few minutes. The $\mathrm{O}_{2}$ contents were $14 \%$ in air and $5.3 \%$ in DO water, which was equilibrated between consumption by cathode reaction and permeation of $\mathrm{O}_{2}$ from outer circumstance. The output characteristics of cells supplied $\mathrm{O}_{2}$ through the gill placed in air and DO water are shown in Fig.4, to compare efficiencies of harvesting oxygen in air and water.

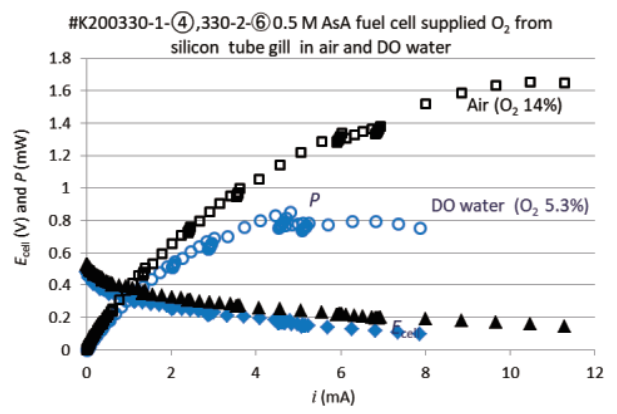

Fig.4 Cells performances harvesting $\mathrm{O}_{2}$ by silicon tube gill placed in air and $\mathrm{DO}$ water, figures in (\%) are $\mathrm{O}_{2}$ contents in gill.

It is noted that the performance using the silicon coil in DO water was improved in comparison with the direct supply of DO water shown in Fig.3. The improvement is supposed to originate from the large diffusion coefficient of gas phase $\mathrm{O}_{2}$ and storage effect in the silicon tube. The result indicates that the harvesting of DO in water could be improved by optimizing the materials and structure of gill.

\section{DEOXIDATION FROM CLOSED CONTAINERS \\ 4.1 Air container}

Three type containers are fabricated as shown in Fig.5 to remove $\mathrm{O}_{2}$ from (f) air, (g) bubbling DO and (h) direct supply of DO water, in addition to Fig.1 (e).

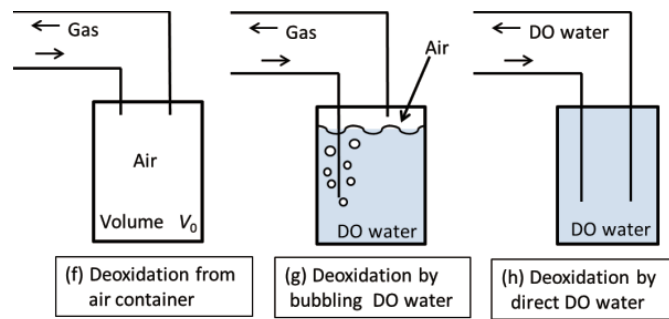

Fig.5 Closed containers for deoxidation from (f) air, (g) bubbling DO water and (h) direct supply of DO water

Fig.6 shows time responses of $E_{\text {cell, }} i$ and $P$ after the 
circulation of gas using the air container Fig.5 (f) with the volume of $V_{0}=2.5 \mathrm{~mL}$. The cell was discharged at $R_{\mathrm{L}}=11$ $\Omega$. It is noted that the output current was limited by the supply rate of $\mathrm{O}_{2}$ to cathode, not limited by fuel supply and external load resistance. The $E_{\text {cell }}$ and $i$ decreased and leveled off in $13 \mathrm{~min}$. The level off to finite values was due to leakage of air into circulation system. The decay of $i$ reflects the $\mathrm{O}_{2}$ content in the system. The content of $\mathrm{O}_{2}$ in the container can be estimated from electric charges, which is obtained by integrating $i$ with time during discharge, namely, $q=\int i \mathrm{dt}$. The $\mathrm{O}_{2}$ content at $35 \mathrm{~min}$ was $1.7 \%$ and equilibrated with the leakage of air, indicating most $\mathrm{O}_{2}$ gas was evacuated.

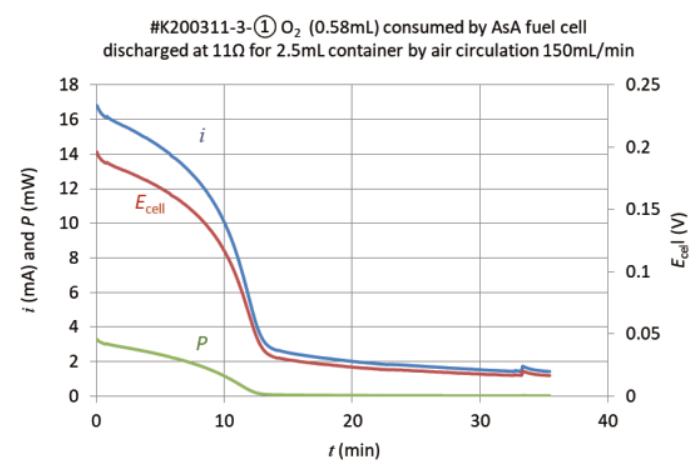

Fig.6 Time responses of cell parameters after gas circulation from air container.

As shown in Fig.1 (a) at the cathode, an $\mathrm{O}_{2}$ molecule is reduced by four electrons, the number of $\mathrm{O}_{2}(j)$ consumed at cathode per second is given [8] by Eq.(1) using (i), where $e$ is electron charge $\left(=1.6 \times 10^{-19} \mathrm{C}\right)$,

$j=\frac{i}{4 e}$

From (1), the flow rate of $\mathrm{O}_{2}\left(v\right.$; volume of $\mathrm{O}_{2}$ flow per second) is given by Eq.(2), using the molar volume of gas $\left(V_{\mathrm{m}}=22.4 \mathrm{~L} / \mathrm{mol}, 0^{\circ} \mathrm{C}, 1 \mathrm{~atm}\right)$,

$v=\frac{V_{m}}{N_{A}} j=\frac{V_{m}}{4 F} i$.

Where, $N_{\mathrm{A}}\left(=6.02 \times 10^{23} \mathrm{~mol}^{-1}\right)$ is the Avogadro Constant and $F\left(e N_{\mathrm{A}}=9.65 \times 10^{4} \mathrm{C} / \mathrm{mol}\right)$ is the Faraday constant. Then the volume of $\mathrm{O}_{2}(V:$ L) consumed during the discharge time is simply given by Eq.(3) in ,

$V=\frac{V_{m}}{4 F} \int i d t=\frac{V_{m}}{4 F} q$

It is convenient to note, $\frac{V_{m}}{4 F}=0.058 \mathrm{~mL} / \mathrm{C}$.

From Fig.6, $q$ is obtained to be $10 \mathrm{C}$, which corresponds to $V=0.58 \mathrm{~mL}$. This $\mathrm{O}_{2}$ content estimated from charges was a little larger than $0.53 \mathrm{~mL}$ estimated from the volume of container, which is due to leakage of air.

\subsection{Bubbling of DO water}

DO in water was removed by bubbling in the container shown in Fig.5 (g). The volume of container was $55 \mathrm{~mL}$ including air portion of $25 \mathrm{~mL}$ and water of $30 \mathrm{~mL}$. The time response of $i$ by discharge at $R_{\mathrm{L}}=11 \Omega$ is shown in Fig.7(a). It took about 4 hours to complete harvesting $\mathrm{O}_{2}$.
The released charge was $92 \mathrm{C}$, which corresponds to the $5.3 \mathrm{~mL}$ of $\mathrm{O}_{2}$. The volume of $\mathrm{O}_{2}$ obtained from the charge coincides to those estimated from the sum of air portion $(5 \mathrm{~mL})$ and $\mathrm{DO}$ in water $(0.19 \mathrm{~mL})$ of the container. The result indicated that the air portion should be minimized to remove $\mathrm{O}_{2}$ by bubbling of $\mathrm{DO}$ in closed container.

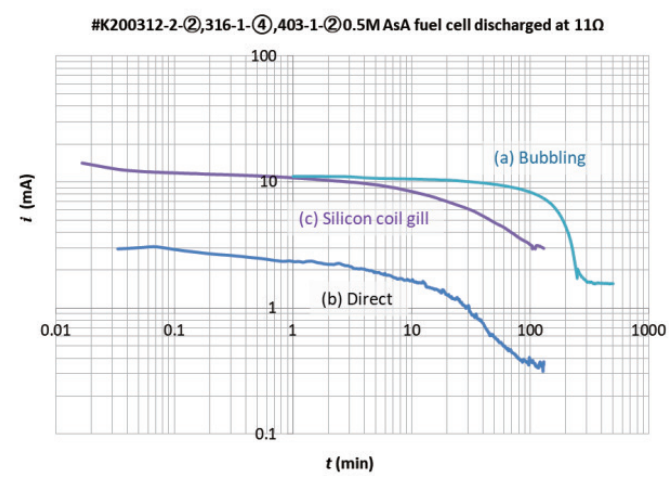

Fig.7 Time responses of $i$ obtained by various deoxidation methods of DO in water, (a) bubbling, (b) direct flow of water and (c) using silicon coil gill

4.3 Deoxidation of DO by direct flow of water

In this experiment the container was filled with DO water of $55 \mathrm{~mL}$. DO water was directly supplied to cathode by circulating water shown in Fig.5 (h). The time response of $i$ is shown by the curve (b) in Fig.7. The $i$ was approximately $3 \mathrm{~mA}$ at the beginning, and then decreased gradually to nearly level off current of $0.35 \mathrm{~mA}$ in 2 hours. The released charge was $5.6 \mathrm{C}$, corresponding to $0.32 \mathrm{~mL}$ $\mathrm{O}_{2}$. The amount of $\mathrm{O}_{2}$ was nearly equal to that estimated from the volume of DO in water being $0.35 \mathrm{~mL}$. It is noted that the $i$ of Fig.7(b) was noisy and smaller than the others, which originated from oxygen deficiency as shown by curve of DO water in Fig.3.

\subsection{Deoxidation of DO by silicon coil gill}

It has been found that the silicon coil gill is efficient to harvest DO in water because of large oxygen permeability coefficient being approximately $4 \times 10^{-8} \mathrm{~cm}^{2} \mathrm{~s}^{-1}[8,9]$. The silicon coil gill with the tube length of $2.5 \mathrm{~m}$ was used to remove DO by the setup shown in Fig.1(e). DO water of $85 \mathrm{~mL}$ was poured in a $100 \mathrm{~mL}$ beaker, and purged with $\mathrm{N}_{2}$ gas at the top. The gas from the gill was circulated by the rate of $100 \mathrm{~mL} / \mathrm{min}$. Curve Fig.7(c) shows the time response of $i$, being similar decay to Fig.7(b). The plots of $i$ vs $t$ is depicted in Fig.8 to show that the $i$ nearly leveled off after 2 hours. The released charge was 38C, corresponding to $2.2 \mathrm{~mL}$ of $\mathrm{O}_{2}$ volume. It is noted that the volume of inner silicon coil and connecting tubes was approximately $10 \mathrm{~mL}\left(\mathrm{O}_{2}\right.$ contents: $\left.2.1 \mathrm{~mL}\right)$ and the volume of DO water was $85 \mathrm{~mL}\left(\mathrm{O}_{2}: 0.54 \mathrm{~mL}\right)$. The total amount of $\mathrm{O}_{2}$ in the system was estimated to be $2.6 \mathrm{~mL}$, which

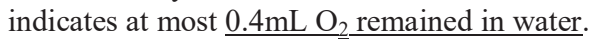

The $\mathrm{O}_{2}$ content in the container was monitored simultaneously by circulating DO water between DO meter and container. To keep the homogeneity in the container, water was stirred at $300 \mathrm{rpm}$. Curves in Fig.8 are time responses of $i$ and content of DO after starting circulation of gas. 


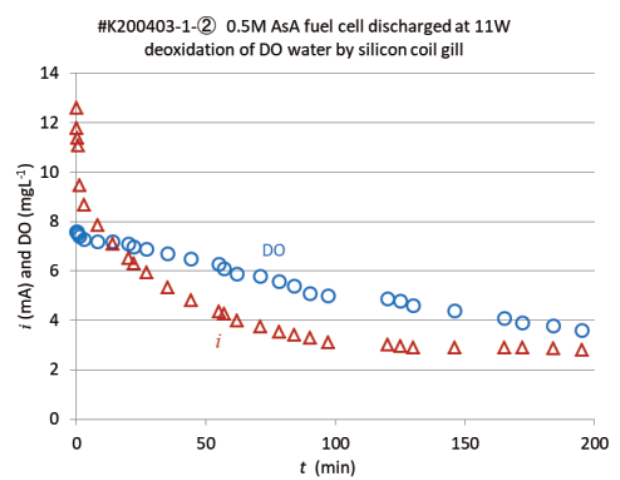

Fig.8 Time responses of DO and $i$ during deoxidation of DO water by silicon coil gill

It is interesting to note that $i$ decreased sharply at the beginning, and then slowly leveled off to $2.8 \mathrm{~mA}$ at approximately $2 \mathrm{hs}$. Contrary to this, the DO dropped linearly all the way. The fact could be explained by a hypothesis that the sharp decrease of $i$ is due to deoxidation of the air part of inner tube, and the level off $i$ is from DO in water. This hypothesis accounts for the linear decrease of DO in water. Furthermore, the residual DO content of $3.5 \mathrm{mgL}^{-1}$ at $3 \mathrm{hs}$ was not harvested yet. The residual DO of $3.5 \mathrm{mgL}^{-1}$ corresponds to $0.21 \mathrm{~mL}$ in volume of $\mathrm{O}_{2}$ in the container, which is estimated from simple calculation using the molar volume $V_{\mathrm{m}}$. The volume of $\mathrm{O}_{2}$ reasonably agrees with the value of $0.4 \mathrm{~mL}$ mentioned previously. It is noted that the level off current of $2.8 \mathrm{~mA}$ indicates the rate of permeated $\mathrm{O}_{2}$ through the gill being $0.16 \mu \mathrm{Ls}^{-1}$ given by Eq.(2).

\section{POWER PERFORMANCE vs. $\mathrm{O}_{2}$ CONTENTS.}

$\mathrm{O}_{2}$ content dependences of cell performances were also studied to explore the limitation of cathodic reaction. As shown in Fig.9, the $E_{0}$ at lower $\mathrm{O}_{2}$ contents increased slightly with increasing $\mathrm{O}_{2}$ contents and leveled off around $0.55 \mathrm{~V}$, which is determined by redox potentials of AsA and $\mathrm{O}_{2}$. The $P_{\max }$ depended linearly on $\mathrm{O}_{2}$ contents, showing no sign of saturation. The fact indicates that the fuel cell system was limited by the $\mathrm{O}_{2}$ contents.

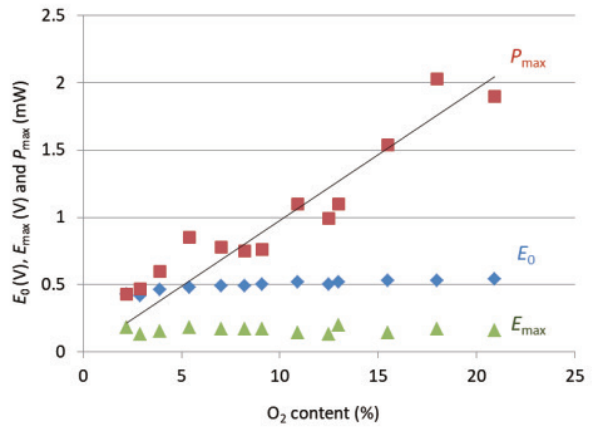

Fig.9 Cell performances at various contents of $\mathrm{O}_{2}$ in silicon coil gill

If the cell performance was controlled by the other factors or variables, for example, fuel concentrations [7] and catalytic reactions, the $P_{\max }$ should saturate in this region. In other words, the $P_{\max }$ can be increased as the function of $\mathrm{O}_{2}$ contents until the saturation by the other factors. In fact, the fuel concentration dependence of $P_{\max }$ showed saturation [7]. We found that this saturation is possibly due to the limitation by $\mathrm{O}_{2}$ contents at this stage of experiment.

\section{SUMMARY}

It was found that fuel cells can be operated by harvesting DO in water by either way of direct water supply, bubbling and artificial gill in water. The cell harvesting DO demonstrated the same performances to that in air within the rated power output. We discussed the relationship between electric charges and contents of oxygen in detail to assure the accuracy of present methods.

The disadvantage of using DO originates to the small diffusion coefficient of $\mathrm{O}_{2}$ in water [10]. That is, the diffusion coefficient in water is $2.0 \sim 2.4 \times 10^{-5} \mathrm{~cm}^{2} \mathrm{~s}^{-1}$, which is approximately 4 orders of magnitude smaller than that in air. This resulted in oxygen deficiency at the cathode in use for heavy loads or high powers. For deoxidation from DO in water using closed containers, the air portion in the system should be exhausted by purging with inert gas before use.

Initial packing of fresh foods, medicines and drinks were perfectly sealed at factories using barrier films. Consumers have to break the seals in use; however, it is hard to repack the stuffs again in inert conditions. The technique mentioned here could be used to deoxidize containers after repacking of stuffs in home. Biofuel cells for this purpose could be manufactured in small size and low cost. Fuels could be sugars or alcohols available in home. The devices may be equipped in home refrigerators.

Acknowledgements

This work was supported by JSPS KAKENHI Grant Number; 16K06280.

\section{References}

[1] B.E. Logan,B. Hamelers, R. Rozendal, U. Schröder, J. Keller, S. Freguia, P. Aelterman, W. Verstraete, K. Rabaey, Environ. Sci. Techno., 40, 5181-5192 (2006).

[2] Y. Zhang, I. Angelidaki, Biosensors Bioelectronics, 38, 189-194 (2012).

[3] N. Fujiwara, S. Yamazaki and K. Yasuda, J. Japan Petroleum Institute, 54, 237-247 (2011).

[4] T. Hibino, K. Kobayashi, P. Lv, M. Nagao, S.

Teranishi, T. Mori, J. Electrochem. Soc., 164, F557

(2017).

[5] K. Kaneto, M. Nishikawa, S. Uto, MRS Advances, 3, 1235-1241 (2018).

[6] K. Kaneto, M. Nishikawa, S. Uto and T. Osawa, Chemistry Letters, 47,1285-1287 (2018).

[7] K. Kaneto, M. Nishikawa, S. Uto, Chemistry Letters, 48, 1533-1536 (2019).

[8] K. Kaneto, S. Uto, Transaction of MRS-J, 45, 131 -134 (2020).

[9] W. L. Robb, Ann. N. Y. Acad. Sci., 146, 119-137 (1968)

[10] X. Zhao, Y. Liu, J. Zou, Q. Wang, H. Liu, H. Zhang, H. Jin, Thermal Science, 23, S781-S787 (2019).

(Received May 17, 2020; Accepted June 11, 2020;

Published Online August 1, 2020) 